Int. J. Morphol.,

38(3):565-569, 2020

\title{
Toward the First Definition of Taste Rosea in Female Breasts: Histological Analysis
}

\author{
La Primera Definición del Sabor Rosea en Mamas Femeninas: Análisis Histológico
}

\author{
Tuba Demirci'; Sevilay Ozmen²; Nazan Aydin ${ }^{3}$; Mehmet Dumlu Aydin ${ }^{4}$; Ozgur Caglar; \\ Ali Ahiskalioglu ${ }^{6}$; Erdem Karadeniz ${ }^{7}$; Betul Gundogdu² \& Ahmet Hacimuftuoglu ${ }^{8}$
}

\begin{abstract}
DEMIRCI, T.; OZMEN, S.; AYDIN, N.; AYDIN, M. D.; CAGLAR, O.; AHISKALIOGLU, A.; KARADENIZ, E. ; GUNDOGDU, B. \& HACIMUFTUOGLU, A. Toward the first definition of taste rosea in female breasts: Histological analysis. Int. J. Morphol., 38(3):565-569, 2020.
\end{abstract}

SUMMARY: Although various neuropsychochemical theories have been established about why breastfeeding mothers feel hedonic sensation, the underlying neural mechanism has not been adequately clarified. We aimed to investigate if there is hedonic sensation-initiated taste-bud like structures stimulated by sugars in the milk-secreting lactiferous ducts of mammary glands of breastfeeding female rats. In this study, twenty-two female rats were chosen which six of the virgin $(n=6)$, six of pregnant ( $n=6)$ and ten of breastfeeding $(\mathrm{n}=10)$. We examined lactiferous ducts/nipples of mammary glands of all animals. They were sacrificed following intracardiac formalin injection, and their breast tissues were removed with covering tissues and fixed with $10 \%$ of formalin solution. After current histological procedures, the tissues were examined by light microscope to assess taste-bud like structures, and their numerical densities were calculated by using stereological methods. Results were analyzed statistically. Taste-buds like structures with neuron-like appendages at the apical ends were discovered in lactiferous ducts. The taste rosea numbers were estimated as $3 \pm 1 / \mathrm{mm}^{3}$ in virgins, $167 \pm 27 / \mathrm{mm}^{3}$ in pregnant and $375 \pm 63 / \mathrm{mm}^{3}$ in breastfeeding animals. The taste rosea numbers were greater in breastfeeding rats than those of virgins and pregnant rats. They named as taste rosea resembling flower bucket which has not been mentioned in the literature so far.

KEY WORDS: Taste rosea; Breast; Breastfeeding pleasure; Pudendal nerve; Milk.

\section{INTRODUCTION}

Being a mother requires maternal functions such as nursing and breastfeeding pleasure; or else, it is impossible to be a mother in all aspects. Although maternal pleasure has been explained by various neuro-behavioral, philosophical, social, and even theological theories, no satisfying mechanism has been found so far. It is easily hypothesized that breastfeeding pleasure created by a neural network should be available in that maternal biological organization. For example; thousands of papers have argued that stimulation of tongue taste buds provides to food choosing, recognizing, and ingestion, which essential for living. The more interesting one, all animals have propagation instinct; but, unless orgasmic sensations, is it possible that sexual relationship is essential for reproduction? Lately, Aydin et al. (2014) have discovered taste bud-like structures essential for creating orgasmic sensation and stimulated by seminal fructose, in penile tissues. Aydin et al. (2018), have described that the presence of taste rosea stimulated by seminal fructose via pudendal nerves in the urethra and glans penis in rats. If so, mammary tissues secreting various sugars such as sucrose, fructose, glucose, and many useful chemicals (Blass \& Shide, 1994) should have taste rosea to initiate and continue maternal actions and behaviors. According to taste rosea related literature, we thought that taste bud-like structures could be available in the mammary glands to provide breastfeeding pleasure of mothers. In our study, we found taste bud-like structures in mammary glands of breastfeeding mothers such as those in the tongue and urethral tissues. Because they are similar to rosea bun-

\footnotetext{
${ }^{1}$ Department of Histology and Embryology, Medical Faculty, Ataturk University, Erzurum-Turkey.

${ }^{2}$ Department of Pathology, Medical Faculty, Ataturk University, Erzurum,Turkey.

${ }^{3}$ Department of Psychology, Humanities and Social Sciences Faculty, Uskudar University, Istanbul, Turkey.

${ }^{4}$ Department of Neurosurgery, Medical Faculty, Ataturk University, Erzurum,Turkey.

${ }^{5}$ Department of Pediatric Surgery, Medical Faculty, Ataturk University, Erzurum,Turkey.

${ }^{6}$ Department of Anesthesiology, Medical Faculty, Ataturk University, Erzurum,Turkey.

${ }^{7}$ Department of General Surgery and Medical Faculty, Ataturk University, Erzurum,Turkey.

${ }^{8}$ Department of Pharmacology, Medical Faculty, Ataturk University, Erzurum,Turkey.
} 
dle, the newly discovered taste buds of breast were named as taste rosea by own ourselves, and this is the first description in the literature.

\section{MATERIAL AND METHOD}

Animals Selection. In this study, twenty-two female Sprague Dawley rats weighing 320-400 g were chosen. Animals were purchased from the Experimental Animal Laboratory of Ataturk University School of Medicine. The rats were housed in standard metal cages and they kept an air-conditioned room with standard humidity under 12/12 hours light/dark cycle. All animals followed for six mating periods, and most of them become pregnant during that period. Rats were subsequently divided into three groups as control $(n=6)$, pregnant $(n=6)$ and breastfeeding $(n=10)$ groups. To observe if there are taste-bud-like structures in breasts, they were sacrificed under general anesthesia, and histopathological examinations were carried out.

Histologic Procedure. The breast and tongue tissues of all subjects were removed. After fixation in $10 \%$ neutral formalin solution, the tissues were passed through alcohol and xylol series and embedded in paraffin blocks. First, tongues and nipples divided horizontally into 10 segments, and then about 20 sections were cut from each block $5 \mathrm{~mm}$ in thickness with a microtome (Leica RM2125RT, Leica Microsystems, Wetzlar, Germany). Some specimens were stained with Hematoxylin \& Eosin (H\&E) and modified aldehyde fuchsin stain. Under the light microscope (NikonEclipse E600, Japan), the anterior parts of tongues and nipples of all animals were examined histologically to compare with each other.

Because of Gustducin antibody recognizes taste cells in taste buds, other sections were stained by using immunostaining techniques in order to detect the expression of gustducin in taste buds in tongue and breasts. The sections were placed on immunohistochemistry device (Leica, BonMax), and then processes of deparaffinization, dehydration, antigen retrieval and blocking of endogenous peroxidases were performed. Primary antibody (Anti-gustducin LifeSpan BioSciences, Inc) was dropped on the sections for $60 \mathrm{~min}$. After washing with phosphate buffer solution, sections were applied a secondary antibody and following, $\mathrm{DAB}+$ chromogen was added and waited until the brown color was observed. Subsequently, slides were stained with hematoxylin for $5 \mathrm{~min}$ and passed through alcohol and xylol series. At the end of the protocol, slides were removed from the device, mouthed with coverslips and evaluated under the light microscope.
Breast Taste Rosea Number Estimation Method. The sections stained with Hematoxylin \& eosin stain and antigustducin antibody were examined under the light microscope. To estimate number of taste rosea, the mean lumen diameter of internal ducts in each 20 consecutive sections were shown with ri1,ri2,ri3,...,ri20; and mean external radius values were shown as $\mathrm{re}^{1}+\mathrm{re}^{2}+\mathrm{re}^{3} \ldots . \mathrm{re}^{20}$. The length of the duct was shown as $h=h 1+\cdots h 20=\Sigma h$ and accepted as the total height of the cylinder-shaped channel. The volume values of all channels were calculated based on the following formula: $\mathrm{V}=\Sigma \Pi \eta\left(\mathrm{re}^{2}-\mathrm{ri}^{2}\right)$. Taste rosea density $(d=n / D u c t)$. The total number of taste rosea/all nipples: $\Sigma \Pi \mathrm{h}=\mathrm{d} \Sigma \Pi \eta\left(\mathrm{re}^{2}-\mathrm{ri}^{2}\right)$ was determined by using physical dissector methods as in our previous article (Aydin et al., 2014; Aydin \& Aydin, 2015).

Statistical Analysis. Results were analyzed by using SPSS 21.0 for Windows. Multiple comparisons among groups were done by Kruskal Wallis test. Using the Mann-Whitney $\mathrm{U}$ test, binary comparisons between groups were assessed. Values are given as the mean \pm standard deviation. P-value $<0.05$ was accepted significant.

\section{RESULTS}

Histological Results. The breast taste rosea were examined with taking reference of the lingual taste buds of each animal. Taste buds were located as an intraepithelial sensory organ, especially in circumvallate papillae in the tongue. They are pale stained structures extending along with the epithelium thickness, and their function is to receive taste sensation.

General Features of Taste Buds. Breast taste rosea were located immediately beneath the epithelium as embedded in the connective tissue surrounding the duct. In the light microscopic view, they appeared slightly paler stained than the epithelial cells, and their cells were lined up vertically to the duct epithelium. In the H\&E stained sections, cell clusters resembling the taste bud were located close to the secretory units of the mammary gland, and each breast taste rosea was surrounded by a delicate connective tissue. Breast taste rosea cells send membranous fibers to neighboring cells among the breast taste rosea cells and their nerves. In order to determine if there were breast taste rosea in breast tissues, gustducin antibody was used. In specimens, neuronal fibers driving from the taste rosea, which resemble those of the tongue, were observed in all breast taste rosea in the ducts. A small nerve fasciculus that penetrates the basal lamina as spiral convolutions, and cell clusters of the breast taste rosea, same as lingual taste 
buds were observed with gustducin immunohistochemical staining. The special characteristics of newly described breast taste rosea were summarized in the legends of Figures 1 to 5 .

Numerical results. The number of breast taste rosea of lactiferous ducts and statistical significance is as follows: The number of breast taste rosea nearly was 1 or 3 in each cubic millimeter on average, whereas in the distal part of the duct opened to the nipple was $4-8 / \mathrm{mm}^{3}$. Breast taste rosea numbers were estimated as $3 \pm 1 / \mathrm{mm}^{3}$ in virgins, $167 \pm 27 / \mathrm{mm}^{3}$ in pregnant and $375 \pm 63 / \mathrm{mm}^{3}$ in breastfeeding animals. Between virgins/pregnant, pregnant/ breastfeeding, and pregnant/breastfeeding, the $\mathrm{p}$ values were $p<0.005, p<0.0005$, and $p<0.00001$, respectively.

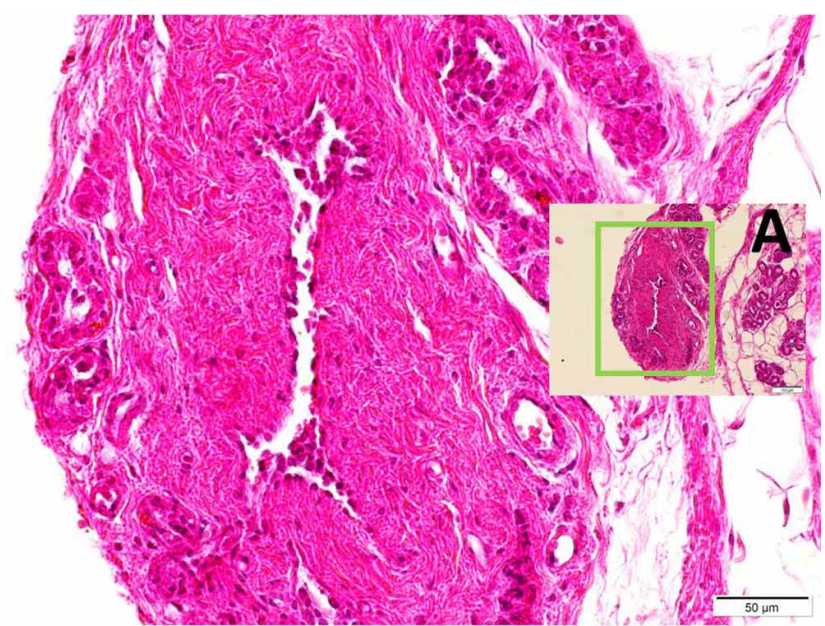

Fig. 1. Histological appearances of the H\&E stained mammary gland in a virgin rat at low and $(\mathrm{A}$, in the green frame, $\mathrm{H} \& \mathrm{E} \times 10)$ and high magnification (Base, H\&E x 20).

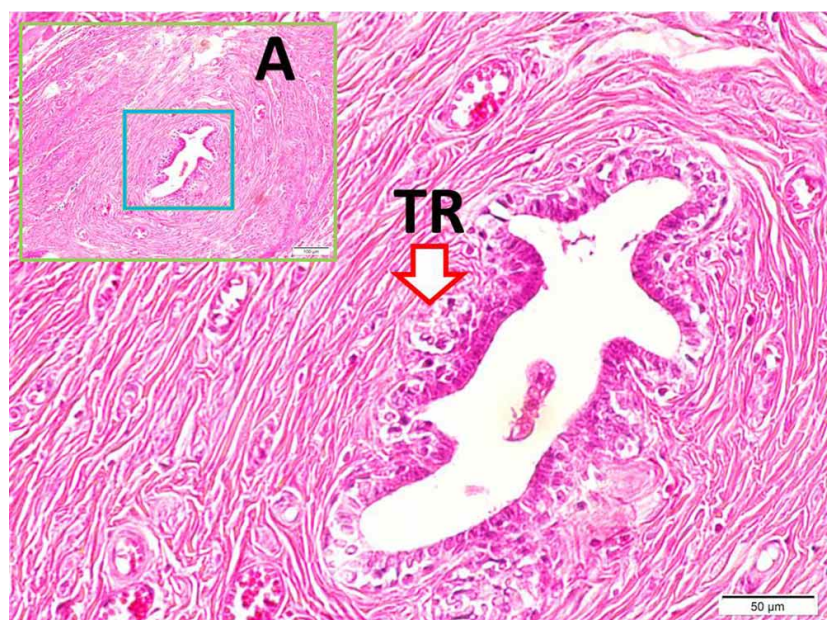

Fig. 2. Histological appearances of the mammary gland in a pregnant rat at low and ( $\mathrm{A}$, in the green frame, $\mathrm{H} \& \mathrm{E} \times 10)$ and high magnification (Base, H\&E x 20). The arrow indicates the breast taste rosea (TR).

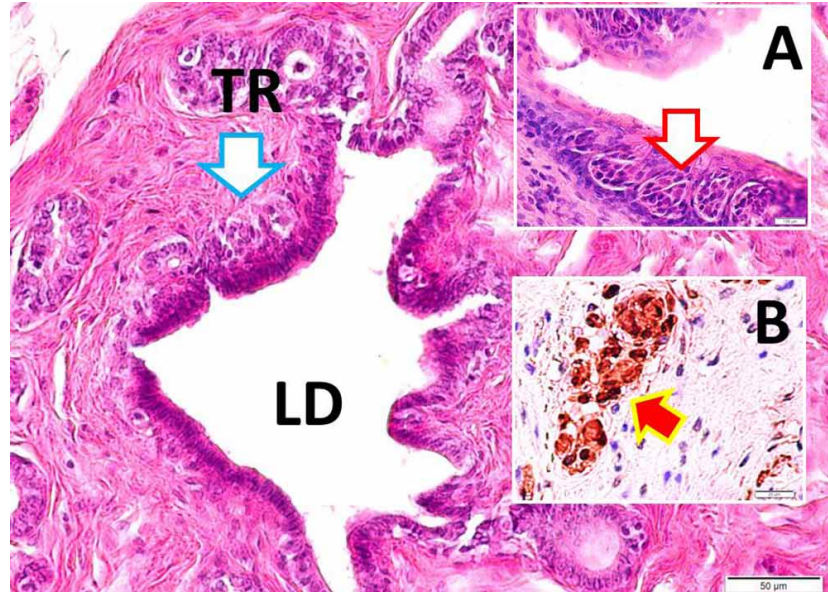

Fig. 3. Histological view of taste rosea of the tongue (A, white arrow, $H \& E$, x10), lactiferous duct (LD) with breast taste rosea (TR) (Base, H\&E, x 20) and magnified appearances of breast taste rosea (B, red arrow, Gustducin immunoreactivity, x40) of a breastfeeding rat. TR, breast taste rosea.

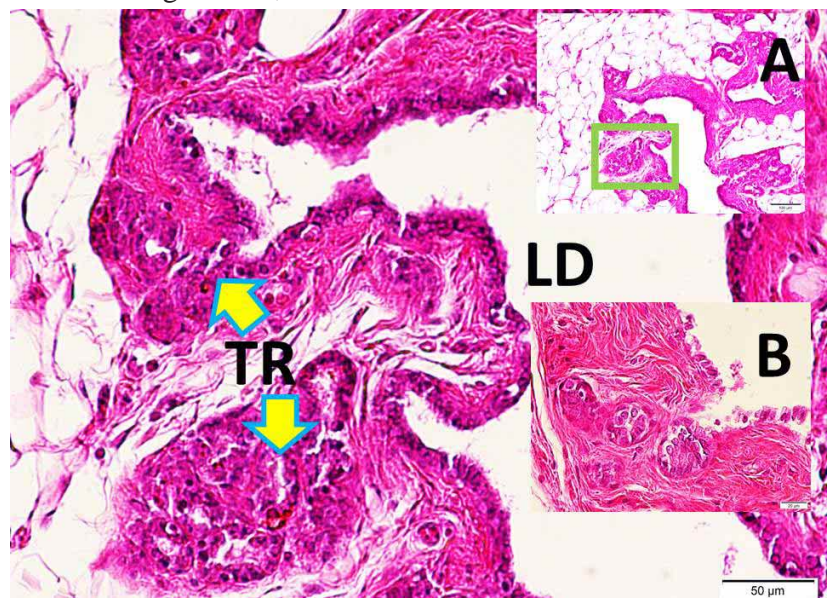

Fig. 4. Histological view of taste rosea (green frame) and lactiferous duct (A, H-E, x10), and magnified appearances of breast taste rosea (TR, yellow arrows) (Base, H\&E, x 20) of a breast-feeding rat. Another view of taste rosea in B (H\&E, x40).

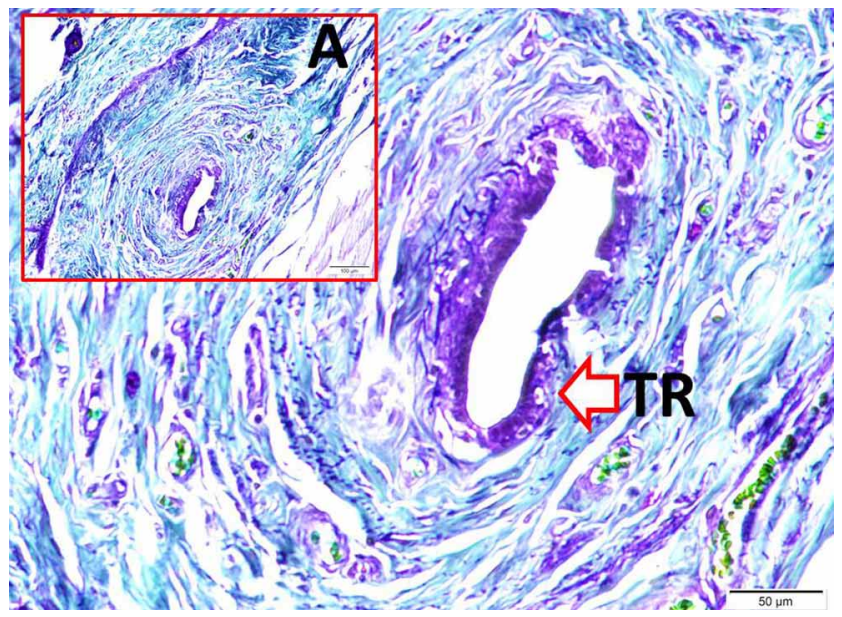

Fig. 5. Histological appearances of the mammary gland (A,Aldehyde fuchsin, $x 10$ ) and high magnification view of breast taste rosea (TR) (Base, Aldehyde fuchsin, x 20) are seen in a pregnant rat. 


\section{DISCUSSION}

The hedonic pleasure mechanism of breastfeeding mothers has not yet been clarified, although there is an essential similarity between taste sensation and hedonic feeling during breastfeeding. In this study, we examined the mammary tissues of breastfeeding rats to investigate whether there was breast taste rosea in lactiferous ducts of breastfeeding mothers.

Taste buds are composed of dark, light, intermediate and basal cells (Suzuki, 2007). The cells of breast taste rosea were similar to intermediate and basal cells. Although the relationship among these cells types is not clear, most authors have expressed that basal cells form to dark cells, and they mature into light cells, light cells then transform to intermediate cells. For reception of sweet, umami, and bitter taste sensations, these cells have taste receptors. Nerve fibers entering into the taste buds form synapses with the taste cells called neuroepithelial cells, and taste sensation is carried to the brain (Gartner, 2015). Taste receptors might be found in intestinal taste sensing cells reacted with a-Gustducin loss in severe colitis (Feng et al., 2018). Karadeniz et al. (2019) showed that olfactory impulses have important effects on mammary gland functions and cytoarchitecture.

Aydin et al. (2014) discovered urethral taste bud resembling cell clusters - such as tongue- awakening with seminal fructose and creating/conveying orgasmic sensation to the central nervous system. Aydin et al. (2018) have described that there are taste rosea stimulated by seminal fructose and innervated by pudendal nerves in the urethra and glans penis in rats. In a recent study, fructose solution was injected into the urethral orifices of rabbits, and the relationship between penile erection and pudendal nerve ganglia was examined. At the end of the study, the existence of the positive correlation between these two situations has been determined. Moreover, it has been reported, that seminal fructose might stimulate taste rosea of the urethra and glans penis via pudendal nerves (Aydin et al., 2018).

Human milk contains many types of bioactive molecules, e.g., oligosaccharides, lactoferrin, Ig, growth factors, and cytokines. These molecules play essential roles in the protection against infections, in organ development and immune system maturation (Jantscher-Krenn et al., 2012; Rigo-Adrover et al., 2017). In another study, it has been reported that sucrose, glucose, and fructose have calming and pain-relieving effects in rats (Blass \& Shide, 1994). In addition, we have thought that especially oligosaccharides provide the mother's pleasure from the breastfeeding process, by stimulating the breast taste rosea located in lactiferous ducts.
In humans, the neurochemical mechanism explained by Liu et al. (2017) reported that milk production augmented a breast specific protein synthesized by breast tissue. Microantomical studies have informed that vago-mammarial network stimulation via baby suckling may contribute to milk synthesis and production during breastfeeding (Quigley $e t$ al., 2017). The neurohumoral mechanism declared that oxytocin and increased vagal nerve activity, stimulates milk flow and facilitate lactation (Uvnäs-Moberg et al., 2001). However, in rodents, the mammary gland has been supplied by the afferent/efferent fibers of pudendal nerves coming from the sacral plexus (Kirk \& Kitchell, 1988). According to the mentioned literature, we easily have drawn the conclusion that parasympathetic network such as vagal/ pudendal nerves could be essential formilk synthesis, production, secretion, flowing, kind maternal behavior, and breastfeeding pleasure.

We detected that the female lactiferous ducts contain many breast taste rosea opened to the lactiferous ducts and had a similar shape of the lingual taste buds. Breast taste buds also have neuron-like extensions at the apical ends of taste buds in the wall of lactiferous ducts. Probably, both of the urethral and breast taste rosea, are innervated by the autonomous pelvic nerves in animals, and vagal nerves in humans, respectively. According to our results, breastfeeding pleasure may originate from breast taste rosea and conveyed with the mentioned nerves to the taste information regulating centers in the spinal cord and brain. We assumed that breast taste rosea stimulated by fructose-galactose found in milk and pelvic-pudendal nerves, may play an important role in the formation of the hedonic sensation of breastfeeding mothers which until now, has not been fully examined.

Readers may wonder if which cellular sensation informed vagal or pudendal nerves about the functions of the breastfeeding mothers. Our response to curious readers is that newly described breast taste rosea, stimulated by milk sugars, is the first stimulated cellular structure. It was shown that taste rosea could be innervated by pudendal nerves in rats. Taste rosea-pudendal network may convey breastfeeding pleasure to spinal cord, milk producing neuroendocrine and other integrative brain centers. In summary, we concluded that the described neural network could regulate function among all milk production related organs.

\section{CONCLUSION}

It is estimated that the vagal/pudendal nerve innervates these breast taste rosea and convey the hedonic sensation of breastfeeding mothers from the breast taste rosea 
to taste information regulating and computing in the higher brain centers which has not been mentioned in the literature so far.

Limitation. If further neuropsychological examinations, biochemical analysis, electrophysiological studies could be performed, the article documents may show better results.

Future Insight. This analysis will open new horizons in the understanding of maternal breastfeeding, rational mechanism of the milk-producing factory, the importance of mother/ infant nutrition, protection of mother/infant life and prevention of psychological, neurological, metabolic, malign and infectious diseases. Taste rosea will have many beneficial effects on mammary gland transplantation, vagal/pudendal nerve stimulation, to restore milk production following various disorders in the future.

DEMIRCI, T.; OZMEN, S.; AYDIN, N.; AYDIN, M. D.; CAGLAR, O.; AHISKALIOGLU, A.; KARADENIZ, E.; GUNDOGDU, B. \& HACIMUFTUOGLU, A. La primera definición del sabor rosea en los mamas femeninas: análisis histológico. Int.J. Morphol., 38 (3):565-569, 2020.

RESUMEN: Existen varias teorías neuropsicoquímicas, referente a la sensación hedónica que sienten las mujeres al amamantar, y el mecanismo neural subyacente. No obstante, estas aún no se aclaran adecuadamente. El objetivo de este estudio, fue investigar si existen estructuras hedónicas iniciadas por la sensación gustativa estimuladas por los azúcares en los conductos mamarios secretores de leche, de las glándulas mamarias de las ratas durante el período de lactancia. En este estudio, se eligieron 22 ratas hembras, seis de estas no preñadas como grupo control, seis preñadas y diez en período de lactancia. Examinamos los conductos lactíferos / pezones de las glándulas mamarias de los tres grupos. Los animales fueron sacrificados por medio de inyección intracardíaca de formalina. El tejido mamario se fijó en solución de formalina al $10 \%$. La muestras histólogicas fueron examinadas a través microscopía óptica con la finalidad de evaluar estructuras con características morfológicas similares a las papilas gustativas. Su densidad de número se calculó utilizando métodos estereológicos. Los resultados fueron analizados estadísticamente. En los conductos mamarios se observaron dos estructuras con con características morfológicas tipo papilas gustativas con apéndices neuronales en los extremos apicales. Los números se estimaron en $3 \pm 1 / \mathrm{mm}^{3}$ en el grupo control, $167 \pm 27 / \mathrm{mm}^{3}$ en gestantes y $375 \pm 63 / \mathrm{mm}^{3}$ en animales lactantes. El número de estructuras características morfológicas similares a las papilas gustativas fue mayor en las ratas amamantando que en el grupo control y que en las ratas preñadas. Conocido como sabor rosea debido a que se asemeja a un ramo de flores, lo que hasta ahora no se ha mencionado en la literatura.

PAlabRaS ClAVE: Sabor rosea; Pecho; Placer de amamantar; Nervio pudendo; Leche.

\section{REFERENCES}

Aydin, M. D. \& Aydin, N. Discovery of The Taste Rosea of Hedonia: Taste Rosea Of Hedonia. Saarbrücken, Lap Lambert Academic Publishing $\mathrm{GmbH}, 2015$.

Aydın, M. D.; Aydın, N.; Dane, S.; Gündogdu, C.; Gürsan, N.; Akçay, F. \& Serarslan, Y. Taste bud-like structures in penile tissues and a predictive neural mechanism of male orgasm: a preliminary hypothesis based on histological evidence. Neurol. Psychiatry Brain Res., 20(3):55-62, 2014.

Aydın, M. D.; Aydın, N.; Kanat, A.; Akca, N.; Ardic, G.; Yolas, C.; Altınkaynak, K. \& Calik, M. The sooth beneath the taste roseas in the urethra and first description of neuro-morpho-chemical mechanism of penile erectile posture in males: an experimental study. Int. J. Neurosci., 128(7):663-9, 2018.

Blass, E. M. \& Shide, D. J. Some comparisons among the calming and painrelieving effects of sucrose, glucose, fructose and lactose in infant rats. Chem. Senses, 19(3):239-49, 1994.

Feng, P.; Chai, J.; Yi, H.; Redding, K.; Margolskee, R. F.; Huang, L. \& Wang, H. Aggravated gut inflammation in mice lacking the taste signaling protein a-gustducin. Brain Behav. Immun., 71:23-7, 2018.

Gartner, L. P. Textbook of Histology E-Book. Amsterdam, Elsevier Health Sciences, 2015.

Jantscher-Krenn, E.; Zherebtsov, M.; Nissan, C.; Goth, K.; Guner, Y. S.; Naidu, N.; Choudhury, B.; Grishin, A. V.; Ford, H. R. \& Bode, L. The human milk oligosaccharide disialyllacto-n-tetraose prevents necrotising enterocolitis in neonatal rats. Gut, 61(10):1417-25, 2012.

Karadeniz, E.; Kocak, M. N.; Ahiskalioglu, A.; Nalci, K. A.; Ozmen, S.; Akcay, M. N.; Aydin, N.; Aydin, M. D. \& Hacimuftuoglu, A. Exploring of the unpredicted effects of olfactory network injuries on mammary gland degeneration: a preliminary experimental study. J. Invest. Surg., 32(7):624$31,2019$.

Kirk, E. J. \& Kitchell, R. L. Neurophysiologic maps of the cutaneous innervation of the external genitalia of the ewe. Am. J. Vet. Res., 49(4):5226, 1988.

Liu, J.; Wang, Y.; Li, D.; Wang, Y.; Li, M.; Chen, C.; Fang, X.; Chen, H. \& Zhang, C. Milk protein synthesis is regulated by T1R1/T1R3, a g proteincoupled taste receptor, through the mTOR pathway in the mouse mammary gland. Mol. Nutr. Food Res., 61(9), 2017. Doi: 10.1002/mnfr.201601017

Quigley, K. M.; Moore, G. A.; Propper, C. B.; Goldman, B. D. \& Cox, M. J. Vagal regulation in breastfeeding infants and their mothers. Child. Dev., 88(3):919-33, 2017.

Rigo-Adrover, M.; Pérez-Berezo, T.; Ramos-Romero, S.; van Limpt, K.; Knipping, K.; Garssen, J.; Knol, J.; Franch, À.; Castell, M. \& Perez-Cano, F. J. A fermented milk concentrate and a combination of short-chain galacto-oligosaccharides/long-chain fructo-oligosaccharides/pectinderived acidic oligosaccharides protect suckling rats from rotavirus gastroenteritis. Br. J. Nutr., 117(2):209-17, 2017.

Suzuki, T. Cellular mechanisms in taste buds. Bull. Tokyo Dent. Coll., 48(4):151-61, 2007.

Uvnäs-Moberg, K.; Johansson, B.; Lupoli, B. \& Svennersten-Sjaunja, K. J. Oxytocin facilitates behavioural, metabolic and physiological adaptations during lactation. Appl. Anim. Behav. Sci., 72(3):225-34, 2001.

Corresponding Author:

Tuba Demirci, Assistant Professor

Ataturk University

Medical Faculty

Department of Histology

Erzurum - TURKEY

Email: drtubademirci@hotmail.com nmda11@hotmail.com

Received: 05-09-2019

Accepted: 27-11-2019 